\title{
SOIL AND VEGETATION FROM NOVI PAZAR (SERBIA) AND ROŽAJE (MONTENEGRO): RADIOACTIVITY IMPACT ASSESSMENT*
}

\author{
Ivanka Antović ${ }^{* * 1}$, Nikola Svrkota², Dalibor Stojanović1 ${ }^{1}$, Mirzeta Hadžibrahimovié ${ }^{1}$, \\ Ranka Žižić², Gordana Laštovička-Medin3 ${ }^{3}$
}

\author{
${ }^{1}$ Department for Biomedical Sciences, State University of Novi Pazar, Novi Pazar, Serbia \\ ${ }^{2}$ Centre for Ecotoxicological Research, Podgorica, Montenegro \\ 3 Faculty of Natural Sciences and Mathematics, University of Montenegro, Podgorica, Montenegro
}

\begin{abstract}
Soil samples from Novi Pazar (Serbia) and Rožaje (Montenegro) were analyzed by the ORTEC HPGe


radioisotope activity concentration for Novi Pazar soil was found to be 27.6, 49.5, 585 and 14.9 Bq/ $\mathrm{kg}$, respectively; while in Rožaje, ${ }^{137 C s}$ activity concentration was found to be significantly higher - from 33.9 to $322 \mathrm{~Bq} / \mathrm{kg}$. The obtained results were used to estimate hazard indices, such as radium equivalent activity (none of the localities showed a radium equivalent activity higher than $370 \mathrm{~Bq} / \mathrm{kg}$ ) and annual gonadal dose equivalent to natural radioisotopes, as well as external terrestrial gamma absorbed dose rate of ${ }^{226} \mathrm{Ra},{ }^{232} \mathrm{Th} /{ }^{228} \mathrm{Ac},{ }^{40} \mathrm{~K}$ and ${ }^{137 \mathrm{Cs} \text {, and }}$ corresponding annual effective dose - used to evaluate excess lifetime cancer risk (then compared with the world average of $0.2 \cdot 10^{-3}$, taking into account external terrestrial radiation - outdoor, i.e., average annual effective dose of o.o7 mSv). Vegetation samples from Rožaje - blackberry (Rubus fruticosus), spruce (Picea abies) and beech (Fagus sylvatica) showed ${ }^{226} \mathrm{Ra}$ activity - 4.03, 1.1 and $0.99 \mathrm{~Bq} / \mathrm{kg}$, respectively; ${ }^{232} \mathrm{Th} /{ }^{228} \mathrm{Ac}-4.5$, 4.22 and $2.89 \mathrm{~Bq} / \mathrm{kg}$, respectively; ${ }^{40} \mathrm{~K}-152,98.4$ and $79.3 \mathrm{~Bq} / \mathrm{kg}$, respectively; ${ }^{137 \mathrm{Cs}}-3.05,3.54$ and $5.24 \mathrm{~Bq} / \mathrm{kg}$, respectively; whilst in Pinus sylvestris from Novi Pazar, they were - 2.7, 2.11, 163, <0.34 Bq/kg, respectively. Soil-plant radioisotope transfer factors were also estimated, and compared with typical ranges given in the UNSCEAR 2008 report. Since the most important radiation source for all terrestrial biota is the activity from soil, the dose rates are also evaluated using known internal (and external - in soil) radioisotope activity concentrations, as well as corresponding the dose conversion coefficients for external and internal exposure to particular radioisotope.
\end{abstract}

Key words: Novi Pazar, Rožaje, soil-vegetation, radiation risks

DOI: $10.21175 /$ RadJ.2016.02.019

\section{INTRODUCTION}

The territories of Novi Pazar (Serbia) and Rožaje (Montenegro) make a borderland between Serbia and Montenegro (illustrated in Fig. 1).



Figure 1. Novi Pazar in Serbia, and Rožaje in Montenegro

Novi Pazar (N. Pazar) municipality has an area of $742 \mathrm{~km}^{2}$ and population of 109327 - based on the Census in 2011, but unofficial information confirm that the population is over 120 ooo [1]. On the other hand,
Rožaje municipality with an area of $432 \mathrm{~km}^{2}$ and population of 22964 (from the Census in 2011) contributes with around $3.13 \%$ to the entire Montenegro area $\left(13812 \mathrm{~km}^{2}\right)$, and with $3.7 \%$ to the total Montenegro population (620 029) [2].

As far as is known, radioactivity impacts for soil and vegetation from N. Pazar have not been analyzed before recent start with one locality - Novopazarska Banja, and the stem of "tree of heaven" Ailanthus altissima (Swingle, 1916) [3]. In order to provide basic information, soils from the N. Pazar urban area were measured for radioactivity, and some health hazard indices were evaluated (radium equivalent activity, annual gonadal dose equivalent, excess lifetime cancer risk) and presented here.

In the past, several gamma spectrometry measurements were performed in the northern Montenegro using in situ [4], HPGe and multidetector (PRIPYAT-2M) spectrometry [5]. Few measurements of radioisotope activities in soil from Rožaje were also performed and showed somewhat higher ${ }^{137 C s}$ activity. Therefore, soil from three different depths from one locality is additionally analyzed in the present study,

\footnotetext{
* The paper was presented at the Third International Conference on Radiation and Applications in Various Fields of Research (RAD 2015), Budva, Montenegro, 2015.
} 
and the results, together with earlier ones, are used to evaluate hazard indices.

In the light of possible radioecological significance, following biocentric approach in a radioecological research (when animals and plants are considered as targets, not only as contaminants to humans [6]), measurements and analyses of vegetation species from N. Pazar and Rožaje were also carried out. This is particularly because the present radiation protection activities should also be focused on non-human biota, not only on humans.

\section{MATERIALS AND METHODS}

Nine samples of uncultivated soil from the urban area of N. Pazar (NP1 to NP9; coordinates in Table 1) were sampled in a standard soil sampling procedure the surface $(0-5 \mathrm{~cm})$ layer from a frame of $25 \mathrm{~cm} \times 25$ $\mathrm{cm}$ [7], while in Rožaje (R; coordinates in Table 1) soil was sampled from (0-5), (5-10) and (10-15) $\mathrm{cm}$ in depth (R-1, R-2 and R-3, respectively).

Table 1. Soil sampling localities

\begin{tabular}{|c|c|}
\hline Locality & Coordinates \\
\hline $\begin{array}{l}\text { NP1 - Generala } \\
\text { Živkovića st. }\end{array}$ & $\begin{array}{l}\mathrm{N} 43^{\circ} \mathrm{O} 8^{\prime} 03.87^{\prime \prime} \\
\mathrm{E} 20^{\circ} 30^{\prime} 40.66^{\prime \prime}\end{array}$ \\
\hline $\begin{array}{l}\text { NP2 - Mihajla } \\
\text { Pupina st. }\end{array}$ & $\begin{array}{l}\text { N } 43^{\circ} \text { O9'16.89" } \\
\text { E } 20^{\circ} 31^{\prime} 40.34^{\prime \prime}\end{array}$ \\
\hline $\begin{array}{l}\mathrm{NP}_{3}-\text { Miodraga } \\
\text { Jovanovića st. }\end{array}$ & $\begin{array}{l}\text { N } 43^{\circ} \mathrm{O} 8^{\prime} 54.37^{\prime \prime} \\
\text { E } 20^{\circ} 31^{\prime} 07.03^{\prime \prime}\end{array}$ \\
\hline $\begin{array}{l}\text { NP4 - Relje } \\
\text { Krilatice st. }\end{array}$ & $\begin{array}{l}\mathrm{N} 43^{\circ} \mathrm{O} 8^{\prime} 46.85^{\prime \prime} \\
\mathrm{E} 20^{\circ} 31^{\prime} 06.36^{\prime \prime}\end{array}$ \\
\hline $\begin{array}{l}\text { NP5 } 5-\text { Gojka } \\
\text { Birčanina st. }\end{array}$ & $\begin{array}{l}\mathrm{N} 43^{\circ} \mathrm{O} 8^{\prime} 33.96^{\prime \prime} \\
\mathrm{E} 20^{\circ} 31^{\prime} 04.19^{\prime \prime}\end{array}$ \\
\hline $\begin{array}{c}\text { NP6 - Ramiza Koče } \\
\text { st. }\end{array}$ & $\begin{array}{l}\mathrm{N} 43^{\circ} \mathrm{O} 8^{\prime} 24 \cdot 35^{\prime \prime} \\
\mathrm{E} 20^{\circ} 30^{\prime} 50.45^{\prime \prime}\end{array}$ \\
\hline NP7 -centre Mladost & $\begin{array}{l}\mathrm{N} 43^{\circ} \mathrm{O} 8^{\prime} 19.41^{\prime \prime} \\
\mathrm{E} 20^{\circ} 30^{\prime} 48.82^{\prime \prime}\end{array}$ \\
\hline NP8 - park & $\begin{array}{l}\mathrm{N} 43^{\circ} \mathrm{O} 8^{\prime} 20.13^{\prime \prime} \\
\mathrm{E} 20^{\circ} 31^{\prime} \mathrm{O} 2.48^{\prime \prime}\end{array}$ \\
\hline $\begin{array}{l}\text { NP9-Vuka } \\
\text { Karadžića st. }\end{array}$ & $\begin{array}{c}\mathrm{N} 43^{\circ} \mathrm{O} 8^{\prime} 18.32^{\prime \prime} \\
\mathrm{E} 20^{\circ} 31^{\prime} 14.91^{\prime \prime}\end{array}$ \\
\hline R - Rožaje & $\begin{array}{l}\text { N } 42^{\circ} 56.296^{\prime} \\
\text { E } 20^{\circ} 12.402^{\prime}\end{array}$ \\
\hline
\end{tabular}

The samples were prepared (dried, sieved), weighed (NP - $0.5 \mathrm{~kg}$ each; R1 - $0.81 \mathrm{~kg}, \mathrm{R} 2-1.144 \mathrm{~kg}, \mathrm{R} 3-$ $1.057 \mathrm{~kg}$ ), and sealed in Marinelli beakers. Measurements were performed using the ORTEC HPGe detectors (40190, relative efficiency - 40 \%; and 30185-S with relative efficiency - $35 \%$ ), calibrated using standard mixtures of gamma emitting isotopes in Marinelli beakers (Czech Metrology Institute). Radioisotope activity concentrations were determined in the standard photopeak analyses (using the total net counting rate under the selected photopeak, photoefficiency, gamma ray intensity and mass of the sample) - ${ }^{137 \mathrm{Cs}}(662 \mathrm{keV}) ;{ }^{226} \mathrm{Ra}$, i.e., ${ }^{214} \mathrm{Bi}$ (609 keV); ${ }^{232} \mathrm{Th}$, i.e., ${ }^{228} \mathrm{Ac}(911 \mathrm{keV}) ;{ }^{\circ} \mathrm{K}(1461 \mathrm{keV})$. Measuring times were $-10000 \mathrm{~s}$ for each NP sample, and 36 040.7, 27 100.3, $27000.4 \mathrm{~s}$ for R-1, R-2 and R-3, respectively.

The radioisotope activity concentrations are used to calculate the external terrestrial gamma absorbed dose rate at $1 \mathrm{~m}$ in air, applying corresponding dose coefficients (in $\mathrm{nGy} / \mathrm{h}$ per $\mathrm{Bq} / \mathrm{kg}$ ) $[8,9]$ in

$$
\begin{aligned}
& \mathrm{D}=\mathrm{A}\left({ }^{226} \mathrm{Ra}\right) \cdot 0.462+\mathrm{A}\left({ }^{232} \mathrm{Th}\right) \cdot 0.604+\mathrm{A}\left({ }^{40} \mathrm{~K}\right) \cdot \\
& 0.0417+\mathrm{A}\left({ }^{137 \mathrm{Cs}}\right) \cdot 0.1243 \text {. }
\end{aligned}
$$

The annual effective dose was calculated using the conversion coefficient from absorbed dose in air to effective dose of $0.7 \mathrm{~Sv} / \mathrm{Gy}$, and outdoor occupancy factor of 0.2 [8], i.e.,

$$
E=D(\mathrm{nGy} / \mathrm{h}) \cdot 8760 \mathrm{~h} / \mathrm{y} \cdot 0.7 \mathrm{~Sv} / \mathrm{Gy} \cdot 0.2 . \text { (2) }
$$

Corresponding excess lifetime cancer risk $(C R)$ due to the dose rate $\mathrm{E}$ is estimated using [10]

$$
\mathrm{CR}=\mathrm{E} \cdot \mathrm{T} \cdot \mathrm{RF},
$$

where $T$ is lifetime expectancy, and $R F$ is risk factor for cancer per Sv. The 70 years lifetime $(T)$ is taken into consideration, as well as $R F$ of 0.05 for the public from the ICRP60 recommendations [11].

Since distribution of ${ }^{226} \mathrm{Ra},{ }^{232} \mathrm{Th}$ and ${ }^{40} \mathrm{~K}$ in soil is not uniform, the radium equivalent activity ( $\mathrm{Ra}$ eq, in $\mathrm{Bq} / \mathrm{kg}$ ) was calculated by standard formula [12]

$$
\mathrm{Ra}_{\mathrm{eq}}=\mathrm{A}\left({ }^{226} \mathrm{Ra}\right)+1.43 \cdot \mathrm{A}\left({ }^{232} \mathrm{Th}\right)+0.07 \cdot \mathrm{A}\left({ }^{40} \mathrm{~K}\right) . \text { (4) }
$$

As an illustration, the annual gonadal dose equivalent ( $\mathrm{G}$, in $\mu \mathrm{Sv} / \mathrm{y}$ ) due to ${ }^{226} \mathrm{Ra},{ }^{23^{2} \mathrm{Th}}$ and ${ }^{40} \mathrm{~K}$ in soil has also been calculated using standard relation [13]

$$
\mathrm{G}=\mathrm{A}\left({ }^{226} \mathrm{Ra}\right) \cdot 3.09+\mathrm{A}\left({ }^{232} \mathrm{Th}\right) \cdot 4.18+\mathrm{A}\left({ }^{40} \mathrm{~K}\right) \cdot 0.314 \cdot(5)
$$

In addition, vegetation samples - leaves/needles of pine Pinus sylvestris (L.) (fam. Pinaceae) from N. Pazar, as well as stem of blackberry Rubus fruticosus (L.) (fam. Rosaceae), bark of beech Fagus sylvatica (L.) (fam. Fagaceae) and leaves/needles of spruce Picea abies (L.) Karst (fam. Pinaceae) from Rožaje, were analyzed for radioactivity of natural ${ }^{226} \mathrm{Ra}\left({ }^{214} \mathrm{Bi}\right),{ }^{232} \mathrm{Th}$

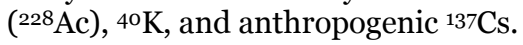

Transfer factor $(T F)$ for particular radioisotope has been evaluated by the ratio: activity concentration in vegetation sample $(\mathrm{Bq} / \mathrm{kg}) /$ activity concentration in soil (Bq/kg).

As is emphasized in the UNSCEAR 2008 report related to the effects of ionizing radiation on nonhuman biota [14], the most important source of radiation for all terrestrial biota (including here considered vegetation) is the soil activity. Therefore, the dose rate can be calculated using [14]

$$
\mathrm{D}=\sum_{i}\left|\mathrm{DCC}_{\mathrm{ext}, i} \cdot \mathrm{A}_{\mathrm{soil}, i}+\mathrm{DCC}_{\mathrm{int}, i} \cdot \mathrm{A}_{i}\right|,(6)
$$

where $D C C_{\text {ext }, i}$ is the dose conversion coefficient for the radioisotope $i$ - external exposure (in $\mu \mathrm{Gy} / \mathrm{h}$ per $\mathrm{Bq} / \mathrm{kg}) ; A_{\text {soil, } i}$ is the activity concentration of radioisotope $i$ in soil (in $\mathrm{Bq} / \mathrm{kg}$ ); $D C C_{\text {int }, i}$ is weighted dose conversion coefficient for internal exposure to radioisotope $i$ (in $\mu \mathrm{Gy} / \mathrm{h}$ per $\mathrm{Bq} / \mathrm{kg}$ ) - assuming a homogeneous activity distribution in the organism; $A_{i}$ is the radioisotope $i$ internal activity concentration in vegetation sample (in $\mathrm{Bq} / \mathrm{kg}$ ). The $D C C_{\text {ext }} s$ given in the 


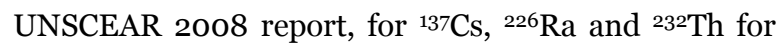
on soil reference organism (pine tree), are: $1.1 \cdot 10^{-4}$, $3.4 \cdot 10^{-4}, 4 \cdot 3 \cdot 10^{-8} \mu \mathrm{Gy} / \mathrm{h}$ per $\mathrm{Bq} / \mathrm{kg}$, respectively, as $D_{\text {Dint }} \mathrm{s}-3.5 \cdot 10^{-4}, 1.4 \cdot 10^{-1}, 2.3 \cdot 10^{-2} \mu \mathrm{Gy} / \mathrm{h}$ per $\mathrm{Bq} / \mathrm{kg}$, respectively [14]. The $D C C_{\text {ext }}$ and $D C C_{\text {int }}$ for ${ }^{40} \mathrm{~K}$ in terrestrial plants found in literature [15] are also used to evaluate dose rate levels due to this radioisotope: $\approx 2.9 \cdot 10^{-4}$ and $\approx 3 \cdot 9 \cdot 10^{-4} \mu \mathrm{Gy} / \mathrm{h}$ per $\mathrm{Bq} / \mathrm{kg}$, respectively.

\section{RESULTS AND DISCUSSION}

\subsection{Soil measurements}

Table 2 shows the results of radioisotope activity measurements in N. Pazar and Rožaje soils.

Table 2. Results of soil measurements

\begin{tabular}{|c|c|c|c|c|}
\hline Soil & $\begin{array}{c}\mathrm{A}(137 \mathrm{Cs}), \\
\mathrm{Bq} / \mathrm{kg}\end{array}$ & $\begin{array}{c}\mathrm{A}(226 \mathrm{Ra}), \\
\mathrm{Bq} / \mathrm{kg}\end{array}$ & $\begin{array}{c}\mathrm{A}(232 \mathrm{Th}), \\
\mathrm{Bq} / \mathrm{kg}\end{array}$ & $\begin{array}{c}\mathrm{A}(40 \mathrm{~K}), \\
\mathrm{Bq} / \mathrm{kg}\end{array}$ \\
\hline $\mathrm{NP} 1$ & $20.3 \pm 0.9$ & $22.6 \pm 1.2$ & $44.8 \pm 2.4$ & $481 \pm 18$ \\
\hline $\mathrm{NP} 2$ & $17.8 \pm 0.8$ & $28.9 \pm 1.3$ & $47.8 \pm 2.5$ & $569 \pm 21$ \\
\hline $\mathrm{NP} 3$ & $11.5 \pm 0.7$ & $29.3 \pm 1.3$ & $57.9 \pm 2.8$ & $569 \pm 21$ \\
\hline $\mathrm{NP} 4$ & $11.9 \pm 0.6$ & $19.2 \pm 1.0$ & $37.2 \pm 2.1$ & $524 \pm 19$ \\
\hline $\mathrm{NP} 5$ & $17.8 \pm 0.8$ & $29.5 \pm 1.3$ & $48.8 \pm 2.6$ & $607 \pm 22$ \\
\hline $\mathrm{NP6}$ & $16.6 \pm 0.8$ & $28.3 \pm 1.3$ & $47.0 \pm 2.6$ & $593 \pm 22$ \\
\hline $\mathrm{NP} 7$ & $17.2 \pm 0.8$ & $35.0 \pm 1.6$ & $63.2 \pm 3.0$ & $672 \pm 24$ \\
\hline $\mathrm{NP} 8$ & $18.3 \pm 0.8$ & $30.4 \pm 1.4$ & $54.1 \pm 2.9$ & $637 \pm 23$ \\
\hline $\mathrm{NP} 9$ & $2.21 \pm 0.39$ & $25.4 \pm 1.3$ & $44.4 \pm 2.4$ & $613 \pm 23$ \\
\hline $\mathrm{R}-1$ & $322 \pm 10$ & $28.9 \pm 1.0$ & $39.8 \pm 1.5$ & $319 \pm 11$ \\
\hline $\mathrm{R}-2$ & $70.6 \pm 2.3$ & $24.8 \pm 0.9$ & $39.4 \pm 1.4$ & $344 \pm 12$ \\
\hline $\mathrm{R}-3$ & $33.9 \pm 1.1$ & $22.6 \pm 0.9$ & $37.4 \pm 1.6$ & $356 \pm 12$ \\
\hline
\end{tabular}

The highest ${ }^{137 \mathrm{Cs}}$ activity concentration measured in the sample $\mathrm{NP} 1(20.3 \mathrm{~Bq} / \mathrm{kg})$ is lower than, for example, that found in the Lazarevac soil $\left(38.1 \mathrm{~Bq} \mathrm{~kg}^{-1}\right.$ [16]), and many folds lower than one measured in Rožaje top soil $(322 \mathrm{~Bq} / \mathrm{kg})$. As follows from the Table 2 data, extremely low ${ }^{137} \mathrm{Cs}$ level was found at the locality NP9 $(2.21 \mathrm{~Bq} / \mathrm{kg})$, while its average activity concentration was calculated to be $14.8 \mathrm{~Bq} / \mathrm{kg}$, with a standard deviation and median -5.6 and $17.2 \mathrm{~Bq} / \mathrm{kg}$, respectively.

An analysis of ${ }^{226} \mathrm{Ra}$ activity concentrations in $\mathrm{N}$. Pazar soil showed - it ranges from 19.2 to $35 \mathrm{~Bq} / \mathrm{kg}$ (which is the world median of mean concentrations [8]), with an average of $27.6 \mathrm{~Bq} / \mathrm{kg}$, and standard deviation and median of 4.63 and $28.9 \mathrm{~Bq} / \mathrm{kg}$, respectively. A mean activity concentration of ${ }^{232} \mathrm{Th}$ $(49.5 \mathrm{~Bq} / \mathrm{kg}$, with a standard deviation of $7.81 \mathrm{~Bq} / \mathrm{kg})$ is found to be higher than the world median of mean concentrations (30 Bq/ kg [8]), with the range and median of (37.2-63.2) and $47.8 \mathrm{~Bq} / \mathrm{kg}$, respectively. Potassium-40 activity concentrations also showed an average value $(585 \mathrm{~Bq} / \mathrm{kg}$, with a standard deviation of $57.7 \mathrm{~Bq} / \mathrm{kg}$ ) and median (593 Bq/kg) higher than the world median of mean concentrations (400 Bq/kg [8]).
A cumulative activity concentration at each $\mathrm{N}$. Pazar locality with a contribution of particular radioisotope (in \%) is shown in Fig. 2.

The dose rates ( $D$ and $E$, calculated using (1) and (2), respectively) are reported in Fig. 3; and showed the range, average, standard deviation and median of (54.7-84.5), 68.9, 8.8 and 68.2 $\mathrm{nGy} / \mathrm{h}$, respectively $(D)$, and (0.07-0.1), $0.08, \quad 0.01$ and $0.08 \mathrm{mSv} / \mathrm{y}$, respectively $(E)$.

The absorbed dose rate average was found to be slightly higher than the average absorbed dose rate in 7 South Europe countries $\left(62 \mathrm{nGy} \mathrm{h}^{-1}\right.$ [8]), or, for example, in Belgrade (60.5 $\mathrm{nGy} \mathrm{h}^{-1}$ [17]). This average (but also median) value is somewhat higher than the global average (57 $\left.\mathrm{nGy} \mathrm{h}^{-1}[8]\right)$.

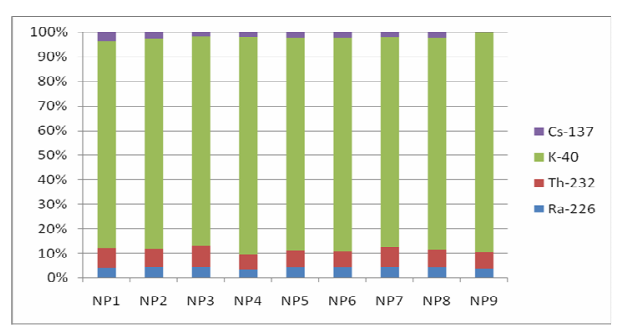

Figure 2. A contribution of radioisotopes to the cumulative activity
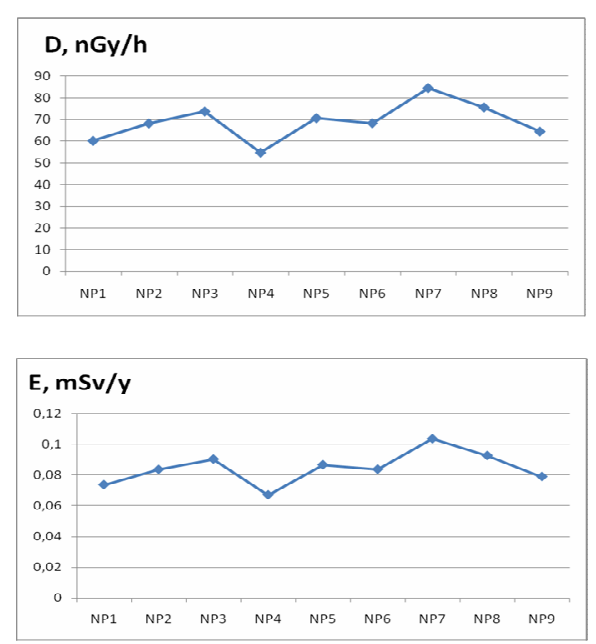

Figure 3. External terrestrial gamma dose rates in N. Pazar: absorbed at $1 \mathrm{~m}$ above the ground (D), and annual effective (E)

The highest determined annual effective dose is for one order of magnitude less than $1 \mathrm{mSv} / \mathrm{y}$, while an $E$ average is slightly higher than the global average, i.e., average annual effective dose of $0.07 \mathrm{mSv}$ from natural radiation sources - external terrestrial radiation, outdoor [8]. Consequently, excess lifetime cancer risk (eq. (3)), shown in Fig. 4, was found to be within the range from $2.35 \cdot 10^{-4}$ to $3.63 \cdot 10^{-4}$, with an average, standard deviation and median of $2.96,0.38$ and 2.93 $\left(\cdot 10^{-4}\right)$, respectively. The $C R s$ average for the world is $2.45 \cdot 10^{-4}$, taking into consideration annual effective dose of $0.07 \mathrm{mSv}$ [8], while, for example, in Kirklareli, Turkey it is from 4.3 to $6.1\left(\cdot 10^{-4}\right)$ [10]. 


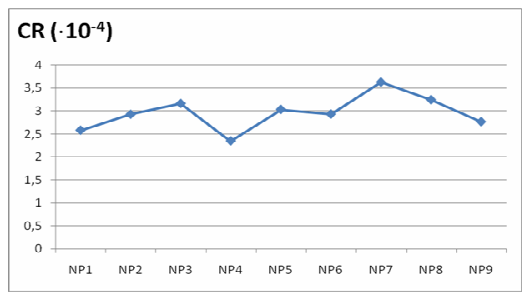

Figure 4. Excess lifetime cancer risk - N. Pazar

The annual gonadal dose equivalent due to natural radioisotopes $(G$, eq. (5)) is presented in Fig. 5, together with radium equivalent activity $\left(R a_{e q}\right.$, eq. (4)); showing minimum, maximum, average, standard deviation and median $-0.38,0.58,0.48,0.06,0.47$ $\mathrm{mSv} / \mathrm{y}$, respectively $(G)$, and 109, 172, 139, 18.6 and 137 $\mathrm{Bq} / \mathrm{kg}$, respectively $\left(R a_{e q}\right)$.
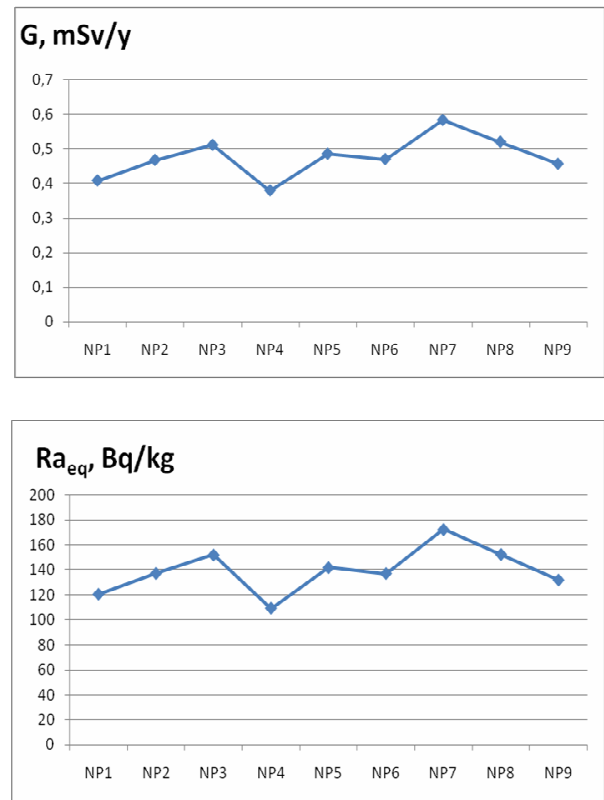

Figure 5. Annual gonadal dose equivalent and radium equivalent activity - N. Pazar

For a comparison, the top Rožaje soil (R-1 in Table 2) showed the $G$ and $R a_{e q}$ value of around $356 \mu \mathrm{Sv} / \mathrm{y}$ and $108 \mathrm{~Bq} / \mathrm{kg}$, respectively; $D$ and $E$ of $90.7 \mathrm{nGy} / \mathrm{h}$, and $111 \mu \mathrm{Sv} / \mathrm{y}$, respectively; i.e., higher than those for N. Pazar - resulting in a higher excess lifetime cancer risk $\left(3.89 \cdot 10^{-4}\right)$, which is lower than an average found for Nikšić in Montenegro (4.4.10 $\left.0^{-4}\right)$ [18].

A previous research showed that in Montenegro soils ${ }^{137} \mathrm{Cs}$ dominantly originated from the Chernobyl accident, and its activity decreases with soil depth (i.e., it is mostly still in the surface soil layer [19]), which is also confirmed in the present study for the Rožaje locality (R).

During in situ measuring campaign in 1994 [4] two measuring points from the Rožaje region were included (Bašća and Kozare) and showed (326 \pm 33$)$ and

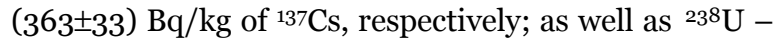
$(15 \pm 2)$ and $(14 \pm 2) \mathrm{Bq} / \mathrm{kg}$, respectively; ${ }^{232} \mathrm{Th}-(17 \pm 2)$ and $(14 \pm 2) \mathrm{Bq} / \mathrm{kg}$, respectively; $4^{\circ} \mathrm{K}-(207 \pm 22)$ and (237 \pm 23$) \mathrm{Bq} / \mathrm{kg}$, respectively.

From the Rožaje area where spruce and beech had been sampled (locality $\left.R^{\prime}\right)$, surface $(0-5 \mathrm{~cm})$ soil was previously analyzed using the PRIPYAT-2M six-

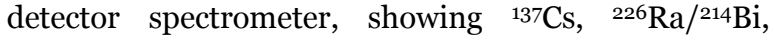
${ }^{232} \mathrm{Th} /{ }^{228} \mathrm{Ac}, \quad{ }^{40} \mathrm{~K}$ activity of $(221 \pm 11), \quad(36.7 \pm 2.5)$, (45.2 \pm 2.8$)$ and (409 \pm 15$) \mathrm{Bq} / \mathrm{kg}$, respectively; and $R a_{e q}$, $G, D, E, C R-130 \mathrm{~Bq} / \mathrm{kg}, 431 \mu \mathrm{Sv} / \mathrm{y}, 88.8 \mathrm{nGy} / \mathrm{h}, 109$ $\mu \mathrm{Sv} / \mathrm{y}, 3.81 \cdot 10^{-4}$, respectively.

\subsection{Vegetation measurements}

The results of vegetation measurements are reported in Table 3. Masses of pine, blackberry, beech and spruce samples were $181.17,171.22,134.7$ and 203.4 g, respectively; as measuring times - 53842 , 73 321, 150179 and 46240 s, respectively.

Table 3. Results of vegetation measurements

\begin{tabular}{|l|c|c|c|c|}
\hline Sample & $\begin{array}{c}\mathrm{A}(137 \mathrm{Cs}), \\
\mathrm{Bq} / \mathrm{kg}\end{array}$ & $\begin{array}{c}\mathrm{A}(226 \mathrm{Ra}), \\
\mathrm{Bq} / \mathrm{kg}\end{array}$ & $\begin{array}{c}\mathrm{A}\left({ }^{232} \mathrm{Th}\right), \\
\mathrm{Bq} / \mathrm{kg}\end{array}$ & $\begin{array}{c}\mathrm{A}(40 \mathrm{~K}), \\
\mathrm{Bq} / \mathrm{kg}\end{array}$ \\
\hline $\begin{array}{l}P . \\
\text { sylvestris }\end{array}$ & $<0.34$ & $2.7 \pm \mathrm{O} .18$ & $2.11 \pm 0.58$ & $163 \pm 7$ \\
\hline $\begin{array}{l}R . \\
\text { fruticosus }\end{array}$ & $\begin{array}{c}3.05 \pm 0.2 \\
3\end{array}$ & $\begin{array}{c}4.03 \pm 0.3 \\
1\end{array}$ & $4.5 \pm 0.64$ & $152 \pm 6$ \\
\hline $\begin{array}{l}F . \\
\text { sylvatica }\end{array}$ & $\begin{array}{c}5.24 \pm 0.3 \\
2\end{array}$ & $\begin{array}{c}0.99 \pm 0.1 \\
2\end{array}$ & $\begin{array}{c}2.89 \pm 0.8 \\
4\end{array}$ & $79.3 \pm 3.7$ \\
\hline P. abies & $3.54 \pm 0.21$ & $1.1 \pm 0.12$ & $<1.22$ & $98.4 \pm 4.8$ \\
\hline
\end{tabular}

The pine sample was taken from the locality $\mathrm{NP}_{3}$ (lower branches with leaves; while soil was sampled at a distance of $1.5^{-2} \mathrm{~m}$ from the tree base). The $T F$ (i.e., activity concentration ratio: $P$. sylvestris/soil) was found to be <0.029, 0.092, 0,036 and 0.286 - for ${ }^{137} \mathrm{Cs}$, ${ }^{226} \mathrm{Ra} /{ }^{214} \mathrm{Bi},{ }^{232} \mathrm{Th} /{ }^{228} \mathrm{Ac}$ and ${ }^{40} \mathrm{~K}$, respectively.

In $R$. fruticosus (sampled at the $\mathrm{R}$ locality) considering surface soil layer R-1, the TFs are 0.009, $0.13,0.113$ and 0.476 , respectively; whilst considering average activities in three soil layers (R-1 - R-3): 0.021, $0.15,0.115$ and 0.447 , respectively.

In $F$. sylvatica (the R' locality) they were found to be $0.024,0.027,0.064$ and 0.194 , respectively; as in $P$. abies $0.016,0.03,<0.027$ and 0.241 , respectively.

It should be noted that data for ${ }^{40} \mathrm{~K}$ (a largest source of natural radioactivity in non-human biota) are given as an illustration only.

Typical ranges for soil-plant $T F s$ for $\mathrm{Ra}$ and $\mathrm{Cs}$ given in the UNSCEAR 2008 report are 0.001-0.1 [14]. In that view, the $R$. fruticosus radium $T F$ is slightly higher, and should be considered in a further study.

It is important to point out that these results cannot be used for the whole $P$. sylvestris (since related to leaves) which can also accumulate radioisotopes in root, stem, cones; for whole $R$. fruticosus, which can also accumulate radioisotopes in root, leaves and fruit itself, or for whole $F$. sylvatica and $P$. abies which also need further research. For example, nominal $T F$ values for reference organism, pine tree (vegetation $(\mathrm{Bq} / \mathrm{kg}) /$ soil $(\mathrm{Bq} / \mathrm{kg})$ ), are $0.2,0.0007$ and 0.001 - for cesium, radium and thorium, respectively [14], while




vegetation $\left(\mathrm{Bq} / \mathrm{kg}\right.$ - vegetation, per $\mathrm{Bq} / \mathrm{m}^{2}-$ soil) for $R$. fruticosus fruit: 0.006-0.05, for Pinus sp. needles: 0.001-0.04, Picea sp. needles: 0.0006-0.02; Fagus sp. bole wood: 0.001-0.002 and leaves: 0.002-0.003 [14].

To illustrate radiation exposure levels, the total dose rates were estimated using eq. (6), assuming a homogeneous activity distribution in the organisms.

From a consideration of the areas where vegetation species were sampled, i.e., $\mathrm{NP}_{3}-P$. sylvestris, $\mathrm{R}-R$. fruticosus (an average radioisotope activity concentration has been used in calculating dose rates), and R' - F. sylvatica, P. abies; an external exposure to radium is found to be around 9.96, 8.64 and 12.5 $\mathrm{nGy} / \mathrm{h}$, respectively, thorium - 2.49, 1.67 and 1.94 $\mathrm{pGy} / \mathrm{h}$, respectively, cesium $-1.26,15.6$ and 24.3 $\mathrm{nGy} / \mathrm{h}$, respectively; potassium - 165, 98.6 and 119

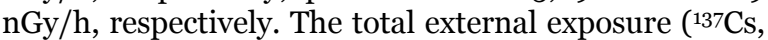
$\left.{ }^{226} \mathrm{Ra},{ }^{232} \mathrm{Th},{ }^{4} \mathrm{~K}\right)$ on these three localities would be $0.18,0.12$ and $0.15 \mu \mathrm{Gy} / \mathrm{h}$, respectively.

Internal exposure of $P$. sylvestris, R. fruticosus, $F$. sylvatica and $P$. abies to considered radioisotopes is evaluated to be $-<0.112,0.728,0.238$ and $<0.222$ $\mu \mathrm{Gy} / \mathrm{h}$, respectively; which means total exposure rate (external and internal) of <0.666, 0.851, 0.393 and $<0.377 \mu \mathrm{Gy} / \mathrm{h}$, respectively.

Comparing these results with ones obtained in an evaluation of doses to non-human biota (terrestrial plants) at Trombay, Mumbai (India) [20], where radiation exposure was found to be 437.2-1044 $\mu \mathrm{Gy} / \mathrm{y}$ (average: $632.8 \mu \mathrm{Gy} / \mathrm{y}$ ) for ${ }^{40} \mathrm{~K}, 2379.8-299763.9$ $\mu \mathrm{Gy} / \mathrm{y}$ (average: $48769 \mu \mathrm{Gy} / \mathrm{y}$ ) for ${ }^{232} \mathrm{Th}, 21.3-2392.2$

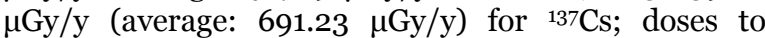
terrestrial biota determined in the present study can be considered as significantly less.

The highest dose rate ( $R$. fruticosus) of $0.02 \mathrm{mGy} / \mathrm{d}$ is significantly below the threshold dose for terrestrial plants $(10 \mathrm{mGy} / \mathrm{d}])$, i.e., below the dose interval (2.525) $\mathrm{mGy} / \mathrm{d}$ from recent literature compilation (ERICA project) - as explained in [6], when effects on plants under chronic exposure could be expected (growth reduction, etc.).

\section{CONCLUSIONS}

None of the considered localities in N. Pazar Serbia and Rožaje - Montenegro showed a radium equivalent activity higher than $370 \mathrm{~Bq} / \mathrm{kg}$. Absorbed dose rates from terrestrial gamma radiation showed an average and median slightly higher than the world's median of average values reported in the UNSCEAR $2000\left(57 \mathrm{nGy} \mathrm{h}^{-1}\right)$. The annual gonadal dose equivalent for soil samples from N. Pazar studied in this work proved to be higher than the world average, while in soil from Rožaje, in the case of one locality, it is comparable with the world's average. With life expectancy taken to be 70 years, a mean excess lifetime cancer risk was found to be $2.8 \cdot 10^{-4}$ for N. Pazar, as well as $3.81 \cdot 10^{-4}$ and $3.89 \cdot 10^{-4}$ for Rožaje.

Transfer factors for ${ }^{137 \mathrm{Cs},}{ }^{226} \mathrm{Ra} /{ }^{214} \mathrm{Bi},{ }^{232} \mathrm{Th} /{ }^{228} \mathrm{Ac}$ from soil to vegetation ranged from 0.009 (for ${ }^{137 \mathrm{Cs}}$ from soil to $R$. fruticosus) to 0.13 (for ${ }^{226} \mathrm{Ra}$ from soil to $R$. fruticosus).

The total dose rate - internal and external exposure of $P$. sylvestris, $R$. fruticosus, $F$. sylvatica and $P$. abies to ${ }^{137} \mathrm{Cs},{ }^{226} \mathrm{Ra} /{ }^{214} \mathrm{Bi},{ }^{232} \mathrm{Th} /{ }^{228} \mathrm{Ac}$ and ${ }^{40} \mathrm{~K}$, is found to be less than $0.021 \mathrm{mG} / \mathrm{d}(<0.666,0.851,0.393$ and $<0.377$ $\mu \mathrm{Gy} / \mathrm{h}$, respectively), i.e., many folds less than the threshold dose for terrestrial plants (10 mGy/d).

Acknowledgement: A part of the research has been done within the project supported by the Ministry of Science of Montenegro (01-683/2013).

\section{REFERENCES}

1. Official site: www.novipazar.rs (in Serbian).

2. MONSTAT, "Statistical Yearbook of Montenegro", Statistical Office of Montenegro, Podgorica, 2012.

3. I.Antović, D. Stojanović, N. Svrkota, R. Žižić, M. Hadžibrahimović, "Opening radioecological research in Novi Pazar - territory of Novopazarska Banja," Proc. $27^{\text {th }}$ Symposium of the Radiation Protection Society of Serbia and Montenegro, Vrnjačka Banja - Serbia, pp. 72-75, 2013. (in Serbian)

4. P. Vukotić et al. "Background gamma-radiation in Montenegro," Proc. IRPA Regional Symposium on Radiation Protection in Neighbouring Countries of Central Europe, Prague, Czech Republic, pp. 477-479, 1997.

5. N. M. Antovic, N. Svrkota, I. Antovic, "Measuring ${ }^{226}$ Ra and ${ }^{232} \mathrm{Th}$ activity in soil and vegetation samples using a method of double $\gamma$-coincidences, " J. Radioanal. Nucl. Chem., vol. 283(2), pp. 313-318, 2010.

6. International Union of Radioecology, http://iuruir.org/upload/About\%2oIUR/radioecology_oslo_pres entation2014.pdf, 2014.

7. HASL-300, "EML Procedures Manual", Environmental Measurements Laboratory, U.S. Department of Energy, 28 Edition, 1997.

8. UNSCEAR, "Sources and Effects of Ionizing Radiation. Annex B: Exposure from natural radiation sources", United Nations, New York, 2000.

9. E. Kapdan, A. Varinlioglu, G. Karahan, "Radioactivity levels and health risks due to radionuclides in the soil of Yalova, northwestern Turkey,” Int. J. Environ. Res., vol. 5(4), pp. 837-846, 2011.

10. H. Taskin et al. "Radionuclide concentrations in soil and lifetime cancer risk due to gamma radioactivity in Kirklareli, Turkey," J. Environ. Radioactiv., vol. 100(1), pp. 49-53, 2009.

11. ICRP Publication 60, "1990 Recommendations of the International Commission on Radiological Protection", 21/1-3, 1991.

12. J. Beretka, P. J. Mathew, "Natural radioactivity of Australian building materials, industrial wastes and byproducts," Health Phys., vol. 48(1), pp. 87-95, 1985.

13. W. Arafa, "Specific activities and hazards of granite samples collected from the eastern desert of Egypt," $J$. Environ. Radioactiv., vol. 75(3), pp. 315-327, 2004.

14. UNSCEAR, "Sources and effects of ionizing radiation. Annex E: Effects of ionizing radiation on non-human biota", 2008 Report to the General Assembly with Scientific Annexes, United Nations, New York, 2011.

15. B. D. Amiro, "Radiological dose conversion factors for generic non-human biota used for screening potential ecological impacts," J. Environ. Radioactiv., vol. 35, pp. 37-51, 1997. 
16. S. S. Nenadovic, M. T. Nenadovic, I. S. Vukanac, M. O. Omerasevic, Lj. M. Kljajevic, "Radiological hazards of ${ }^{137 \mathrm{Cs}}$ in cultivated and undisturbed areas," Nucl. Technol. Radiat. Prot., vol. 26(2), pp. 115-118, 2011.

17. Lj. Jankovic Mandic, S. Dragovic, "Assessment of terrestrial gamma exposure to the population of Belgrade (Serbia)," Radiat. Prot. Dosim., vol. 140(4), pp. 369-377, 2010.

18. N. M. Antović et al., "Radioactivity impact assessment of Nikšić region in Montenegro," J. Radioanal. Nucl. Chem., vol. 302 (2), pp. 831-836, 2014.
19. N. M. Antovic, P. Vukotic, N. Svrkota, S. K. Andrukhovich, "Pu-239+240 and Cs-137 in Montenegro soil: their correlation and origin," $J$. Environ. Radioactiv., vol. 110, pp. 90-97, 2012.

20. R. K. Singhal, K. Ajay, N. Usha, A. V. R. Reddy, "Evaluation of doses from ionizing radiation to nonhuman species at Tromay, Mumbai, India," Radiat. Prot. Dosim., vol. 133(4), pp. 214-222, 2009. 